OUR DAILY BREAD 



\title{
OUR DAILY BREAD
}

The Peasant Question and Family Farming in the Colombian Andes

\author{
NOLA REINHARDT
}


University of California Press

Berkeley and Los Angeles, California

University of California Press, Ltd.

London, England

(C) 1988 by

The Regents of the University of California

Library of Congress Cataloging-in-Publication Data

Reinhardt, Nola.

Our daily bread : the peasant question and family farming in the Colombian Andes / Nola Reinhardt.

p. $\mathrm{cm}$.

Bibliography: p.

Includes index.

ISBN 0-520-06225-6 (alk. paper)

1. Family farms-Colombia. 2. Peasantry-Colombia. I. Title. HD1 476.C7R45 1989

338. $1 \operatorname{og} 861-\mathrm{dc} 19$

88-14370

CIP

Printed in the United States of America

$\begin{array}{lllllllll}1 & 2 & 3 & 4 & 5 & 6 & 7 & 8 & 9\end{array}$ 